\begin{tabular}{|c|l|}
\hline Title & Human responses to the Y ounger Dryas in Japan \\
\hline Author(s) & Nakazawa, Yuichi; Iwase, A kira; A kai, Fumito; Izuho, Masami \\
\hline Citation & $\begin{array}{l}\text { Quaternary International, 242(2), 416-433 } \\
\text { https://doi.org/40.1016/.quaint.2010.12.026 }\end{array}$ \\
\hline Issue Date & 2011-10-15 \\
\hline Doc URL & http://hdl.handle.net/2115/49041 \\
\hline Type & article (author version) \\
\hline File Information & QI242-2_416-433.pdf \\
\hline
\end{tabular}

Instructions for use 


\section{Human responses to the Younger Dryas in Japan}

Yuichi Nakazawa ${ }^{1,2, *}$, Akira Iwase ${ }^{3}$, Fumito Akai ${ }^{4}$, Masami Izuho ${ }^{3}$

${ }^{1}$ Zao Board of Education, Enda, Aza Nishiurakita 10, Zao Town, Katta-gun, Miyagi 989-0892, Japan

${ }^{2}$ Department of Anthropology, 1 University of New Mexico, Albuquerque, NM 87131, USA

${ }^{3}$ Archaeology Laboratory, Faculty of Social Sciences and Humanities, Tokyo Metropolitan University, 1-1, Minami Osawa, Hachioji City, Tokyo 192-0397, Japan

${ }^{4}$ Kagoshima Board of Education, Shimofukumoto 3763-1, Kagoshima City, Kagoshima 8910144, Japan

E-mail addresses: yuichi_nakazawa@hotmail.com (Y. Nakazawa), yiu51057@nifty.com (A. Iwase), fumito-akai@nifty.com (F. Akai), izuhom@tmu.ac.jp (M. Izuho)

*Corresponding author. Fax: 0224-33-3831 


\begin{abstract}
The effect of the Younger Dryas cold reversal on the survival of Late Glacial hunter-gatherers in the Japanese Archipelago is evaluated, through a synthetic compilation of ${ }^{14} \mathrm{C}$ dates obtained from excavated Late Glacial and initial Holocene sites $\left(332{ }^{14} \mathrm{C}\right.$ dates from 88 sites $)$. The estimated East Asian monsoon intensity and vegetation history based on the loess accumulations in varved sediments and pollen records in and around the Japanese Archipelago suggest an abrupt change to cool and dry climate at the onset of Younger Dryas, coupled with the Dansgaard-Oeschger Cycles as recorded in Greenland. The chronometric placement of sites based on an assessment of ${ }^{14} \mathrm{C}$ dates show that the site numbers decrease from the $\mathrm{B} \emptyset$ llingAllerød to Younger Dryas and increase from the Younger Dryas to Preboreal. However, human population dynamics inferred from a site distribution analysis was little changed from the previous Bølling-Allerød and to the following Preboreal. Moreover, hunter-gatherers consistently employed ceramic pottery technology since its emergence prior to the onset of Younger Dryas, while the quantity of ceramic vessels that were undermined during the Younger Dryas dramatically increased at the onset of the Holocene, implying that a substantial change in hunter-gatherer socioeconomy occurred after the end of Younger Dryas.
\end{abstract}

Keywords: Younger Dryas, Bølling-Allerød, Preboreal, East Asia, Japanese Archipelago, pottery technology 


\section{Introduction}

A central issue in studying prehistoric hunter-gatherer society is to discuss whether and how extent paleoclimatic oscillations affected human adaptive responses. The interglacial-glacial cycles originally predicted by Milankovitch are now proven to coincide with fluctuations in oxygen-isotope signatures $\left(\delta^{18} \mathrm{O}\right.$ values $)$, recorded in ice cores and marine and terrestrial sediments (e.g., Dansgaard et al., 1993; Hays et al., 1976; Kawamura et al., 2007; Wang et al., 2008; Yuan et al., 2004). In East Asia, recent studies on the oxygen-isotope signatures in cave stalagmites in China (e.g., Sabano and Hulu Caves) have traced millennium-scale fluctuations climatic records reliably furnish climatic frameworks within which changes and variability in adaptive strategies of human societies are legitimately concerned. In developing the relationship between environmental conditions and variability in human adaptations, the Younger Dryas cold reversal, dated to $12,900-11,600$ cal. B.P. (11,000-10,000 B.P.), gives an appropriate chronometric framework. There are several advantageous characteristics in employing the Younger Dryas. The first advantage is that the Younger Dryas is a short climatic episode, but long enough for exploring changes in human societies at the Pleistocene/Holocene transition. An abrupt climatic transition from the previous Bølling-Allerød interstadial and its abrupt termination at the end of the Pleistocene (Alley et al., 1993; Wang et al., 2001) give the prospect that this millennium climatic event could have had a substantial effect on socioeconomy of hunter-gatherer societies. The second reason is that archaeological records are abundant for the Late Glacial, especially after the end of the Last Glacial Maximum (LGM) around 17-16,000 B.P. It was during the Late Glacial when hunter-gatherers came to settle various regions in the worldwide (e.g., Gamble, 1993; Goebel et al., 2008; Hoffecker et al. 1993; Straus, 1996). Because hunter-gatherer archaeological records at the regional scale come to be highly visible in 
the Late Glacial, it is worthwhile to make a comparison of archaeological records at the regional scale. Among the other geographic locations in East Asia, because of the large number of excavated sites in late Upper Pleistocene (ca. 35,000-10,000 B.P.), the Japanese Archipelago now can provide sufficient data sets to evaluate the impact of Younger Dryas to human adaptations. The third reason is on the emergence of complexity in hunter-gatherer societies. The Late Glacial archaeological records in the Far Eastern Asia in and around the Japanese Archipelago witnessed a variety of technological innovations, notably pottery and bow and arrow technologies (see Fig. 4.). Among the debatable topics including how technological innovation contributed to changes in hunter-gatherers lifeways including on the beginning of sedentary lifeway (e.g., Nishida, 1986; Pearson, 2006), the beginning of broad-spectrum subsistence strategies (e.g., Aikens and Akazawa, 1996) and the introduction of horticultural economies with rice domestication (e.g., Bleed and Matsui, 2010; Matsui and Kanehara, 2006), the emergence of pottery technology is a big question in world prehistory (e.g., Clark, 1969; Ikawa-Smith, 1976; Rice, 1999). It will give a new avenue toward an understanding of evolution in social complexity at the cultural transition from the Paleolithic to the Neolithic, through the clarification of how new technologies changed ways of resource exploitations that in turn altered variability in archaeological records (e.g., Cohen, 1998; Keally et al., 2003; Kuzmin, 2006; Yasuda, 2000).

Given these environmental and archaeological backgrounds of the Late Glacial, the present paper addresses the question as to whether and how the Younger Dryas impacted huntergatherers in the insular environment of Japan, situated in the mid to high latitudes of the Northern Hemisphere. Since the Japanese Archipelago is isolated from the Continental East Asia, it is an independent geographic entity that can serve as a natural regional framework, but its 
internal geographic variability is high because of elongated extension and diverse landscapes. Thus, regionally diverse geography needs to be seen as something that potentially influences the adaptive variability of hunter-gatherers. In this sense, it is reasonably hypothesized that adaptive variation in hunter-gatherer lifeways is expected and that variability in the Late Glacial archaeological records was affected by both macro-climatic condition (i.e., the Younger Dryas cold reversal) and ecological diversity at the regional scale. The Japanese Archipelago serves as an ideal geographic entity for testing the hypothesis.

The main goal of this paper is to discuss changes in human occupations during the Younger Dryas in the Japanese Archipelago. This will be achieved through a synthetic compilation of currently available radiocarbon dates obtained from excavated archaeological sites, and comparison of dates among the three continuous periods of Bølling/Allerød, Younger Dryas, and Preboreal. The second goal is to see whether there were any socioeconomic changes at the transitions to the onset and at the end of the Younger Dryas. Since Pleistocene archaeological sites in the Japanese Archipelago are virtually sterile in osteological and botanical remains on which we can reconstruct human subsistence economy in resource exploitations, here we will assess socioeconomic change through an examination of foraging patterns at the regional scale by the analysis of site locations (i.e., latitudes and altitudes). Since the emergence of pottery is the notable technological innovation at the end of Pleistocene in East Asia, in employing the new data sets of artifact assemblages associated with radiocarbon dates, we also assess the issue as to whether and how the late Late Glacial hunter-gatherers maintained ceramic technology during the Younger Dryas. Results will illuminate aspects of the human technological and socioeconomic responses to the Younger Dryas, and further suggest implications as to how Late Glacial hunter-gatherers adapted in the insular environments of East Asia. 


\section{The environmental background of the Japanese Archipelago during the Younger Dryas}

While the boundary of Japanese land is politically determined, it is the latitudinally long chain of islands, situated in the mid to high latitudes along the northwestern Pacific Rim. The main islands called Hokkaido, Honshu, Shikoku, and Kyushu, from north to south, extend along a northeast-southwest axis (see Fig. 3.). These four main islands are situated between $45-30^{\circ} \mathrm{N}$, and $145-130^{\circ} \mathrm{E}$. With the Japan Sea to the west, the archipelago stretches parallel to China, Korea, and Russian Far East. While the land bridge between the Korean Peninsula and Kyushu Island (southern Japan) disappeared by the end of Middle Pleistocene, the present masses of islands were shaped after the end of the LGM as rising sea level submerged the land bridges between southern Sakhalin Island and northern Hokkaido, and plains that had lain in between Shikoku and the western Honshu (e.g, Keigwin and Gorbarenko, 1992; Tada, 1999). By about 15,000 years ago, around the time when Bølling/Allerød interstadial began, the present shape of the Japanese Archipelago was nearly completed. Unlike the mainland of East Asia, the oceans that surround the archipelago (the Japan Sea to the west, and the Pacific Ocean to the east) affect the circulations of currents and East Asian monsoons that blow from the west (Igarashi and Oba, 2006). The geographic characteristics of the Japanese Archipelago stretching across the mid to high latitudes have created both comparable, but also unique climatic signatures from the global standards recorded in high latitudes around the Greenland. The varved sediments in Lake Suigetsu and Lake Tougouike (western Japan) have sequential records of the intensity of East Asian monsoon (Fukusawa, 1999). Fukusawa's (1999) pioneering study of varved sediments suggests that there was a Younger Dryas signature in the fluctuations of eolian loess originating 
from the Chinese Loess Plateau on the mainland of East Asia. His analysis of varved layers from the Lake Suigetsu has demonstrated that the cooling event at approximately 11,320 B.P. (Kitagawa and van der Plicht, 1998) may corresponds with the 100 year cooling event from 11,300 to 11,400 years ago recorded in the Greenland ice core (GISP 2) (Stuiver et al., 1995). Moreover, since illite and quartz grains that are transported as eolian loess by the Asian summer monsoon, Fukusawa (1999: 240-241) analyzed the quartz flux (mg/cm ${ }^{2} \mathrm{yrs}$ ) in late fall to early spring varves in Lake Tougouike to estimate the paleoclimatic fluctuations in the mid latitudes, given the understanding that the amount of quartz grains in verved sediments reflects the moisture at the inner Asia. In correlating the oxygen isotope ratios in the GISP 2 (Stuiver et al., 1995), an abrupt increase of quartz flux that suggests the onset of dry and cold climate in inner Asia is 350 years earlier than the onset of Younger Dryas (Fukusawa, 1999: 241). This estimate is further supported by reconstructed changes in mean annual temperatures recorded in the pollen stratigraphy of Lake Suigetsu, western Japan (Nakagawa et al., 2005). The cool and dry climate during the Younger Dryas has been also recorded in the vegetation history. A recent synthesis of the pollen records (Takahara et al., 2010) from terrestrial and marine sediments in and around the Japanese Archipelago show that the vegetation changes were in response to the DansgaardOeschger cycles registered in Greenland (Dansgaard et al., 1993). The pollen records obtained from Japan and Taiwan demonstrates that the Younger Dryas was characterized by the abundance of cold conifers and cool conifers relative to temperate deciduous broadleaf trees and an increase of upland herbs. Consistent with the sedimentary changes in varved layers, the pollen records from Lake Suigetsu show cold temperatures during the Younger Dryas (Nakagawa et al., 2005). Contrary to the vegetation, faunal community in the Younger Dryas has not been well reconstructed because of the lack of paleontological and zooarchaeological records. While a 
substantial absence of faunal remains in the Pleistocene archaeological sites in Japan makes it difficult to discuss human prey species, some paleontological records around the LGM have demonstrated that the two faunal communities inhabited in the Japanese Archipelago: the faunal group represented by Naumann's elephant (Palaeoloxodon naumanni) and giant deer, and the group with mammoths (Akazawa 2005). The faunal group with Naumann's elephant was originally migrated from the Continental Asia through land bridges during the middle Middle Pleistocene (ca. 400,000 - 300,000 B.P.), whereas the group with mammoths (also including bison and moose) first appeared in the Japanese Archipelago around 360,000 - 340,000 B.P., migrated from the northern land bridge (Takahashi and Izuho 2010). The group with Naumann's elephant mainly inhabited in southwestern Honshu disappeared by the onset of LGM. In contrast, the faunal group with mammoths inhabited in Hokkaido during the LGM, but likely disappeared after the LGM, as climate started to become warmer in the post-LGM period (Iwase et al. 2010). Given the current understanding of paleontological records of the Late Pleistocene large mammalian community in the Japanese Archipelago, megafauna seem to be disappeared by the onset of Younger Dryas. Although there is no confirmative evidence of megamammal hunting in the Japanese Pleistocene sites, without having large mammalian community in the post-LGM landscapes, the largest terrestrial species targeted by humans in the Younger Dryas were presumably mid-bodied mammals notably represented by boars and sika deer, which were continuously preyed in the Holocene (e.g., Niimi 2010; Nishimoto 1991).

\section{An evaluation of the Younger Dryas Sites}

\subsection{The sample and analytical procedure}


Following the records in the Greenland ice cores (Stuiver et al., 1995), we employ as dates for Younger Dryas, beginning at 12,900 cal. B.P. and ending 11,650 cal. B.P. The sites falling in the range dated between 14,700 - 12,900 cal. B.P. are placed in the Bølling/Allerød, while those falling in the range dated to $11,650-8,500$ B.P. are situated in the Preboreal. Table 1 lists the ${ }^{14} \mathrm{C}$ dates that are attributed to the terminal Pleistocene and the initial Holocene. The list has attributes including site names, regions, sampled locations, laboratory numbers, methods of radiocarbon dating, materials, $\delta^{13} \mathrm{C}$ values, uncalibrated ${ }^{14} \mathrm{C}$ dates, calibrated ${ }^{14} \mathrm{C}$ dates, and references. Placement of archaeological sites in Younger Dryas was done through a critical evaluation of the published radiocarbon dates. Sources of ${ }^{14} \mathrm{C}$ dates were extracted from Kanomata (2007), summarizing dates from the published reports of the Late Glacial and initial Holocene in northern Japan. The ${ }^{14} \mathrm{C}$ dates for the study period were also extracted from Keally et al. (2003). In addition, the list of dates for the sites typologically attributed to the Initial Jomon Phase, recently dated by the National Museum of History and Ethnology (Onbe, 2007) was used. The radiocarbon dates listed in these references were gathered by referring to the relative ages constructed by a unique chronological scheme of Jomon pottery types, namely the Incipient and Initial Jomon periods (see Fig. 1.). The lithic assemblages without having the ceramic vessels are also included. Whenever it was necessary, we also used the dates published in site monographs.

In Table 1, we provide calibrated ${ }^{14} \mathrm{C}$ dates using the OxCal version 3.10 (Bronk Ramsey, $1995,2001)$. Since many sites have yielded multiple ${ }^{14} \mathrm{C}$ dates, it was first necessary to determine as to whether the site retains reliable evidence for the purpose of this exercise. First, we assessed multiple ${ }^{14} \mathrm{C}$ dates from a single site to determine the chronozone for the site. In the first step, we assign specific chronozone to each date, based on the calibrated dates. The ${ }^{14} \mathrm{C}$ calibrated dates are shown with $68 \%$ confidence limits around the means. After assigning the chronozones, we 
examine whether the $68 \%$ confidence intervals overlap or not. If they are separated by multiple series of ${ }^{14} \mathrm{C}$ dates, we further examined whether the separate ranges of ${ }^{14} \mathrm{C}$ dates fall in mutually different chronozones or all fall in a single chronozone. If all series of dates fall in separate groups, but are assigned to be a single chronozone, we judge that site has credible dates and assigned it to that chronozone. If separated groups exhibit multiple chronozones, we judge that the chronometric placement of that site is undetermined, unless a majority of dates (> $60 \%$ ) fall into a single chronozone.

<Fig.1.>

$<$ Table 1>

$<$ Table 2>

\subsection{Results}

The calibrated ${ }^{14} \mathrm{C}$ dates with determined chronozones for sampled sites are summarized in Table 2. We examined $332{ }^{14} \mathrm{C}$ dates from 88 sites. A total of seven Younger Dryas sites are identified. It is only $8 \%$ of the total sample of dated sites (7/88). From north to south, these are: Hachazawa B (Tohoku), Takihata (Tohoku), Kannoki (Chubu [Central Japan]), Toya (Northern Kanto), Tako Minamihara (Northern Kanto), Kounoki (Tokai), and Obaru D (Northern Kyushu). The contextual backgrounds of the Younger Dryas sites summarized below are from the original site reports. 
Hachazawa B: The date was obtained from the charcoal sampled from the bottom of the pit in Excavation Zone B. No cultural remains are associated.

Takihata: The charcoal dated for ${ }^{14} \mathrm{C}$ was obtained from the cobble concentration (cobbles are fire-cracked rocks). A cluster of potsherds (nail-pressed) and hand axes were recovered around the cobble concentration. A likely contemporaneous pit-house-like feature was located about $10 \mathrm{~m}$ away from the cobble concentration.

Kannoki: A series of consistent dates were obtained from charcoals and soils sampled from pits (SK35, SK37, SK38) and burnt sediments (a hearth) (SF01). No descriptions of the features and associated artifacts are available in the report.

Toya: The site has numerous pit traps. The dated specimen was obtained from an organic remain left on the bottom of the pit trap. No culturally diagnostic artifacts are associated with the pit.

Tako Minamihara: The dated specimen was obtained from the organic remains left on the bottom of the trap-pit. No culturally diagnostic artifacts are associated.

Kounoki: The dates for the Younger Dryas were obtained from various features, including a pit house (SH220, SH234), pits (SK201, SK 213), and hearth (SZ215).

Obaru D: The dates for the Younger Dryas were obtained from various features, including a burnt pit house (SC003), another pit house (SC014, SC029), burnt sediments (SX051), and features located on the surface depression (\#4001). A number of lithics and ceramics were recovered from the features. The upper structure of the burnt pit house was reconstructed from the locations of charred postholes. 
These site contexts suggest that the hunter-gatherers in the Younger Dryas constructed pit houses, as identified in the Kounoki and Obaru D. Even though pottery was readily used in this period, it is notable that hunter-gatherers retained cobble concentrations that possibly functioned as cooking facilities (e.g., boiling, grilling).

The numbers of sites dated to the Bølling/Allerød and Preboreal are 21 and 36, respectively. Although some of them possibly fall into the Younger Dryas, a total of eight sites - Juno, Kamikuroiwa Cave Layer 6, Kariyagano, Kigano, Monzen, Ogakubo, Saishikada Nakajima (B), and Torihama shell midden - could not be assigned as to a specific chronozone because these sites have calibrated dates that cross the ranges of multiple chronozones. Our identification of sites to the chronozones in the Late Glacial demonstrates that site numbers decrease from the Bølling/Allerød to the Younger Dryas, and increase from the Younger Dryas to Prebreal (Fig. 2.). Because the duration of Younger Dryas - approximately 1,000 years - is shorter than the previous and following periods, duration of the three chronozones needs to be standardized in assessing site numbers. The mean site numbers per millennium (represented by gray bars in Fig. 2.) obscures the observed difference in site numbers among the three chronozones, while the number of the Younger Dryas sites is still the lowest among the three periods. This leads the question as to whether human population contraction occurred in the Japanese Archipelago during the Younger Dryas. In the following section (3.3.), we will further evaluate the extent of population dynamics in the Younger Dryas through an examination of site locations at the regional scale in the archipelago.

$<$ Fig.2.> 
Three sites exhibiting dates greater than 14,700 cal. B.P. fall into the range prior to the onset of the Bølling/Allerød interstadial. These are the Fukui Cave Layer III (northern Kyushu), Maeda Kochi site (Southern Kanto), and Odai Yamamoto I site (Tohoku, northern Honshu). All of these sites have pottery, suggesting that the Late Glacial hunter-gatherers employed pottery technology. The Fukui Cave Layer III has yielded pottery (linear-relief style) associated with wedge-shaped microblade industry (Hayashi, 1970; Serizawa, 1978). Our calibrated dates suggest that the Odai Yamamoto I site yielded pottery dating to $15,300-14,650$ cal. B.P. This site had been credited for with having the earliest pottery industries in East Asia (Kuzmin, 2006; Nakamura et al., 2001), until an older pottery industry dated to $18,300-15,430$ cal B.P. was discovered from the Yuchanyan Cave, southern China (Boaretto et al., 2009). Although the issue as to whether the earliest pottery technology occurred in the Japanese Archipelago either by local invention or diffusion from other regions in East Asia is debatable, it is notable that the Late Glacial hunter-gatherers developed pottery technology during the early phase of Late Glacial in East Asia, presumably during the colder Heinrich Event 1 (Denton et al., 2005), before the onset of the Bølling/Allerød and after the LGM. Putting the issue of the origin of pottery technology into the context of the effect of Younger Dryas on human socioeconomy, it is critical to concern as to whether already invented (or introduced) pottery technology was maintained in the technological inventories of hunter-gatherers during the Younger Dryas. We will examine this issue in section of 3.4 .

\subsection{On the effect of the Younger Dryas on human foraging}


Based on the dated sites that were sorted into the three chronozones, we examine as to whether hunter-gatherers changed their foraging areas in response to the Younger Dryas climatic regime. In order to evaluate a trend in foraging patterns of the late Late Glacial hunter-gatherers, here we test two hypotheses. The first hypothesis aims to answer the question as to whether the humans migrated from the north to the south under the cooler climatic conditions initiated at the onset of the Younger Dryas. As described above, cooler signatures recorded in pollen spectra in central Japan coincided with the Younger Dryas (e.g., Kumon et al., 2009; Takahara et al. 2010). If humans shifted their foraging areas toward the south, the Younger Dryas sites are expected to be distributed more southern area than the sites attributed to the Bølling/Allerød. The second hypothesis addresses the question as to whether hunter-gatherers changed their foraging strategies in response to changed seasonality in the Younger Dryas. Since the interpretation of changes in oxygen-isotope ratios in the Greenland ice cores has shown that the Younger Dryas is marked by considerably colder winters than during the preceding and succeeding chronozones (Broecker, 2006; Denton et al., 2005), as well as decrease in summer monsoons (Wang et al., 2001). With the increased seasonality with long winters and cool summers, plant productivity and abundance of species in mammalian community were diminished. The overall decline in biomass could have resulted in available resources for humans across landscape to become patchy. In this circumstance, it is expected that hunter-gatherers changed their foraging strategy to acquire resource patches that were expected to be more scattered on plains, lowlands, and lower terraces than high plains, and mountains. Given the rugged terrain of the Japanese Archipelago, foragers in the Younger Dryas were expected to shift their foraging areas toward lower elevations. 
The first hypothesis is tested by a comparison of latitudes of site coordinates among the Bølling/Allerød, Younger Dryas, and Preboreal. Fig. 3. compares the latitudes of sites among the three chronozones. The sites are spread across the entire Archipelago, although the frequency of the Younger Dryas sites is lower and the geographic distribution is slightly more "centered" in the archipelago than in the previous and following periods. The Younger Dryas sites are distributed between 40 and $33^{\circ} \mathrm{N}$, and no sites are identified below $33^{\circ} \mathrm{N}$ or above $41^{\circ} \mathrm{N}$. In plotting the site locations on the map of Japanese Archipelago (Fig.4.), sites attributed to the Younger Dryas are absent in Hokkaido and southern Kyushu. No sites in Hokkaido are even recognized during the Preboreal. Although current understanding is that pottery technology were absent during the Younger Dryas and Preboreal in Hokkaido until its resurgence around 8,000 B.P. (Sato et al., 2010), this would not necessarily indicate that Hokkaido was uninhabited for 3000 years between ca. 11,000 to 8000 B.P. Unlike the situation in China where the LGM sites are absent above $41^{\circ} \mathrm{N}$ (Barton et al. 2007; Elston et al. 2010), humans inhabited Hokkaido at least since the onset of the LGM (ca. 21,000 B.P.) and more than 200 late Upper Paleolithic sites mostly characterized by microblade technology has been identified (Nakazawa et al., 2005). Late Glacial hunter-gatherers survived rigorous climatic condition in the LGM could have been capable in dealing with environmental circumstances in the Younger Dryas. Since a not small number of late Upper Paleolithic sites lack radiometric dates, we speculate that a portion of the Late Glacial sites with microblades can be attributable to the Younger Dryas. By the same token, no Younger Dryas sites in southern Kyushu (lower than $33^{\circ} \mathrm{N}$ ) could be the result of sampling error. A total of nine sites in southern Kyushu evenly falls into the Bølling/Allerød ( $\mathrm{N}=3)$, Preboreal $(\mathrm{N}=3)$, and Undetermined $(\mathrm{N}=3)$, although the sample size is so small that it is not allowed to examine non-randomness of site numbers among different chronozones. Conversely, 
if the pattern in latitudes of sites was not the result of sampling error, the observed limitation in site distribution suggests that the overall human population in the archipelago likely had contracted in some degree. Regardless of whether there is sampling error or not, no Younger Dryas sites distribute in regions lower than $33^{\circ} \mathrm{N}$ and above $41^{\circ} \mathrm{N}$, implying that population contraction, if any, was not associated with directional human migrations. In other words, the kinds of human migrations that altered both regional and pan-regional population dynamics represented in the American Continents during the Late Glacial (e.g., Anderson and Gillam, 2000; Dillehay, 2000; Faught, 2008; Hamilton and Buchanan 2007; Rogers et al. 1991; Steele et al. 1998; Surovell, 2000), were unlikely to have occurred during the Younger Dryas in the Japanese Archipelago.

In testing the second hypothesis, we compared the altitudes of Younger Dryas sites with those of the Bølling/Allerød and Preboreal sites. Because the altitudes of sites are not normally distributed (Ryan-Joiner normality test: $\mathrm{RJ}=0.881, \mathrm{~N}=39, \mathrm{p}<0.01$ ), the medians of altitudes were compared among the three chronozones. The median of attitudes for the Younger Dryas sites $(65 \mathrm{~m})$ is much lower than those of the other $($ Bølling/Allerød $=184 \mathrm{~m}$, Preboreal $=$ 173m).The non-parametric statistical comparison, however, failed to reject the null hypothesis that the altitudes of sites among the three chrnonozones are not different at the 5\% level (Kruskal-Wallis Test: $\mathrm{H}=2.59, \mathrm{df}=2, \mathrm{p}=0.274$ ). This is because the sites located above $600 \mathrm{~m}$ above sea level (e.g., Kannoki and Seikosanso B in the montane area in Central Japan) were consistently occupied throughout the three periods of the Late Glacial. Even though the median of site elevations for the Younger Dryas is low, humans lived almost as widely across entire regions in Japan, regardless of altitudinal differences vis-à-vis the Bølling/Allerød and Preboreal. Thus, hunter-gatherers favored to move in lower elevations during the Younger Dryas, but no 
prominent sign of change in the overall patterns of site locations. This implies that change in foraging areas with respect to altitudinal movement was little.

<Fig.3.>

$<$ Fig.4.>

\subsection{The role of pottery technology among humans in the Younger Dryas}

Fig. 5. illustrates the representative classes of stone tools and ceramic vessels, compared across the three regions (Kyushu, Kanto/Chubu/Tokai/Western Honshu, and Hokkaido/Tohoku), through the Bølling/Allerød, Younger Dryas, and Preboreal chronozones. In addition to ceramic vessels, a variety of chipped stone tools and groundstones were used since the Bølling/Allerød interstadial and variation of lithic tool assemblages was continuously observed among industries throughout the Younger Dryas and Preboreal. In association with the emergence of pottery, projectile points (arrowheads) are usually found in the lithic industry of the Bølling/Allerød. This suggests that hunter-gatherers employed bow and arrow technology with the pottery before the onset of the Younger Dryas. Numerous classes of groundstone artifacts (e.g., polished stone axes, anvils, hammerstones, saddle querns, grinding stones) that are ubiquitous in the Holocene Jomon sites were readily found from the final Late Glacial sites, notably those in the southern Kyushu $\left(31-30^{\circ} \mathrm{N}\right)$ (Pearson, 2006; Shinto, 1999).

As noted earlier, we examined how final Late Glacial hunter-gatherers maintained the earlier invention of pottery technology. If ceramics was identified as a technological inventory of the 
Younger Dryas hunter-gatherers, it will suggest that humans have consistently employed this peculiar cooking utensil in their subsistence practice. If it was not, it will imply that humans radically changed their subsistence technology responded to new ecological circumstance in the Younger Dryas. In testing these expectations, we collected quantitative data on ceramic sherds from the late Late Glacial sites, assuming that the number of potsherds gives a gross estimate of the quantity of vessels that were consumed by site occupants. Since the variability and quantity of archaeological assemblages can vary depending on sample size (Grayson, 1984; Leonard and Jones, 1989), we examined the relationship between number of identified specimens (NISP) for ceramic sherds and trench size at excavated sites $\left(\mathrm{m}^{2}\right)$, followed by a comparison of quantities of potsherds among the three chronozones (i.e., Bølling/Allerød, Younger Dryas, and Preboreal). Although some lack of quantitative data of potsherds makes the sample size reduce to be 24 , the logarithmic NISP (Ryan-Joiner normality test: RJ $=0.99, \mathrm{~N}=24 \mathrm{p}>0.1$ ) and logarithmic trench size (Ryan-Joiner normality test: $\mathrm{RJ}=0.944, \mathrm{~N}=24, \mathrm{p}=0.023$ ) are not correlated (Pearson's $\mathrm{r}=$ $0.066, p=0.758)$, suggesting that there is no sample-size effect on quantity of potsherds recovered from the sampled sites. Table 3 summarizes the basic statistics for the NISP of pottery compared among the three periods. Only two pottery assemblages (i.e., Kounoki and Takihata) are assigned to the Younger Dryas. The sample size is smaller than those of the previous and following periods. Also, the quantity of ceramic vessels for the Younger Dryas as represented by the NISP is notably smaller than those of the other periods. The median size of pottery assemblage in Bølling/Allerød is about 50\% larger than those of the Younger Dryas, while the median size for Preboreal is four times larger than that of the Younger Dryas. Moreover, the maximum number of potsherds in the Preboreal is 66 times larger than that of the Younger Dryas. While pottery was the newly invented material first appeared in the archaeological records 
during the Bølling/Allerød, its quantity increased dramatically at the onset of the Holocene, suggesting that the use of pottery came to be a requisite among the hunter-gatherer societies since the beginning of the Holocene. This supports an earlier observation by Keally et al. (2003). A notable observation stemming from our data is that the frequency of use among ceramic vessels diminished during the Younger Dryas. Pottery was consistently maintained in the subsistence technology among the late Late Glacial hunter-gatherers, while its importance in technological inventories seems to have been smaller during the Younger Dryas.

<Fig. 5.>

$<$ Table 3>

\section{Discussion}

Our synthetic evaluation of calibrated ${ }^{14} \mathrm{C}$ dates compiled from the excavated Late Glacial and initial Holocene sites in the Japanese Archipelago demonstrates a decrease in site numbers in the Younger Dryas. The effect of the Younger Dryas on the socioeconomy of the huntergatherers in Japan was investigated through the comparison of foraging patterns at the regional scale and the role of pottery technology among the three contiguous chronozones: the Bølling/Allerød, Younger Dryas, and Preboreal. Foraging patterns assessed by latitudes and altitudes of the sampled sites do not show a significant change in the Younger Dryas. The role of pottery technology in the Late Glacial and initial Holocene hunter-gatherer inventories was quantitatively assessed by the NISP of potsherds (i.e., number of pieces from ceramic vessels). 
Use of pottery, beginning during the Bølling/Allerød, was undermined in the Younger Dryas, and resurged at the onset of the Holocene. Decreased site numbers during the Younger Dryas may be a signature of population contraction. However, the degree of population contraction was not large enough to create small isolated populations that in turn would have substantially reduced the number of active potters. Moreover, knowledge of pottery technology would have been firmly shared among the hunter-gatherer populations, presumably maintained for many generations during the Younger Dryas. Large social networks (Wobst 1974) through which verbal information and goods were circulated were probably maintained throughout the late Late Glacial (ca. 16-15,000 cal. B.P. and onward), as hunter-gatherers started to exploit various small resource patches (e.g., aquatic resources, nuts and geophytes in forestry environment, particularly in Honshu, Shikoku, and Kyushu) that were more densely distributed than those of the LGM.

The present data are insufficient to broach the big question about how the emergence of sedentary lifeways was related to the technological innovations and broad-spectrum subsistence economy in hunter-gatherer societies. While the incompleteness of dietary data makes it difficult to reconstruct the subsistence economy of the Late Glacial hunter-gatherers, the first obvious signature of broad-spectrum has been seen in the intensive exploitation of aquatic resources that left large shell middens since the beginning of Holocene (e.g., Aikens and Akazawa, 1996; Nunn et al., 2006). Since the Natsushima shell midden (southern Kanto), known as the earliest shell midden in Japan (Sugihara and Serizawa 1957) was now likely fallen in 11,500 - 9000 cal. B.P. (Habu 2004; Kudo 2004), it is plausible that the emergence of shell middens on the Japanese Archipelago was during the Preboreal. This phenomenon occurred simultaneously with the quantitative increase of ceramic vessels, may have been the cultural consequence of a systemic 
change in human resource exploitations and foraging patterns. However, pottery production and use did not come to be large-scale for 4500 years of the Bølling/Allerød and Younger Dryas until the onset of Preboreal, while the mean site numbers did not increase dramatically at the transition from Younger Dryas to the Preboreal (Fig. 2.). This may suggest that the increased quantity in ceramic vessels in the Preboreal sites was not an outcome of rapid demographic change in the beginning of the Holocene. Rather, we suggest that an increased reliance on pottery could be the consequence of changes in human foraging strategies. We also think that the presence of shell middens may not necessarily be a rapid response to widening human diet breadth and population increase at the onset of Holocene. Potential foraging areas for pursuing terrestrial mammals after the end of LGM gradually decreased as the transgression of shorelines towards inlands submerged the Pleistocene plains to shape present rugged and narrow coastal plains on the Japanese Archipelago. Besides the decreased foraging areas, since mobility of mid-bodied terrestrial mammals (e.g., boar, sika deer) was lower than that of the Pleistocene large-bodied mammals inhabited on the lower plains (e.g., bison, giant deer, moose, reindeer), cost induced from searching the terrestrial games ("searching costs" sensu Stephens and Krebs [1986:17]) would have decreased as well. This made humans repetitively forage on particular segments on the Holocene landscapes, but face to spend energy and time to exploit various small patches including low-ranked resources with low caloric returns (e.g., shellfish, geophytes) and high handling cost (e.g., deciduous acorn with toxic tannin). In some regions where coastal plains were small (e.g., Tohoku, northeastern Honshu), hunter-gatherers could have crossed over both coastal (e.g., estuaries, marshes, lagoons) and inland (e.g., valleys, hills, mountains) areas to exploit various resource patches. Decreasing foraging territories and widening prey choices occurred after the Younger Dryas would have eventually led hunter-gathers to be sedentary that 
in turn accelerated rate of innovation to produce a variety of ceramic vessels served for cooking and storage. Having recognized the increased biogeographic diversity in the Japanese archipelago after the end of Younger Dryas, this scenario only delivers a general framework of changes in foraging strategies and prey choices, which future investigations into the archaeological records at micro-regional scale will evaluate.

\section{Acknowledgements}

An earlier version of this paper was presented at the symposium of the Younger Dryas in the $75^{\text {th }}$ annual meeting of the Society for American Archaeology in St. Louis. We are grateful to Profs. Lawrence Straus and Ted Goebel for their invitation to the symposium. We thank Lawrence Straus, Robert Elston, Takashi Tsutsumi, Matt Dawson, Takuya Yamaoka, Masashi Suzuki, and Keiko Kitagawa for helping us to obtain relevant information while working on the present research topic. Comments from anonymous reviewers are constructive to improve the manuscript. Errors, biases, and shortcomings in the paper, if any, are our responsibility. 


\section{References}

Aikens, C.M., Akazawa, T., 1996. The Pleistocene-Holocene transition in Japan and adjacent Northeast Asia: climate and biotic change, broad-spectrum diet, pottery, and sedentism. In:

L.G. Straus, B.V. Eriksen, J.M. Erlandson, D.R. Yesner (Eds.), Humans at the End of the Ice Age, Plenum Press, New York, pp. 215-227.

Akazawa, T., 2005. Pleistocene peoples of Japan and the peopling of the Americas. In: R. Bonnichsen and K. Turnmire (Eds.), Ice Age Peoples of North American: Environments, Origins, and Adaptations of the First Americans, Second Edition, Texas A\&M University Press, pp. 95-103.

Alley, R.B., Meese, D.A., Shuman, C.A., Gow, A.J., Taylor, K.C., Grootes, P.M., White, J.W.C., Ram, M.A., Waddington, E.D., Mayewski, P.A., Zielinski, G.A., 1993. Abrupt increase in Greenland snow accumulation at the end of the Younger Dryas event. Nature 362, 527-529.

Anderson, D.G., Gillam, J.C., 2000. Paleoindian colonization of the Americas: implications from an examination of physiography, demography, and artifact distribution. American Antiquity 65, 43-66.

Barton, L., Brantigham, P.J., Ji, D., 2007. Late Pleistocene climate change and Paleolithic cultural evolution in northern China: implications from the Last Glacial Maximum. Developments in Quaternary Sciences 9, 105-128.

Bleed, P., Matsui, A. 2010. Why didn't agriculture develop in Japan?: a consideration of Jomon ecological style, niche construction, and the origins of domestication. Journal of Archaeological Method and Theory 17, 356-370. 
Boaretto, E., Wu, X., Yuan, J., Bar-Yosef, O., Chu, V., Pan, Y., Liu, K., Cohen, D. Jiao, T., Li, S., Gu, H., Goldberg, P., Weiner, S., 2009. Radiocarbon dating of charcoal and bone collagen associated with early pottery at Yuchanyan Cave, Hunan Province, China. Proceedings of National Academy of Science 106, 9595-9600.

Broecker, W.S., 2006. Abrupt climate change revisited. Global and Planetary Change 54, 211 215.

Bronk Ramsey, C., 1995. Radiocarbon calibration and analysis of stratigraphy: the OxCal Program. Radiocarbon 37, 425-430.

Bronk Ramsey, C., 2001. Development of the radiocarbon calibration program. Radiocarbon 43, $355-363$.

Cheng, H., Edwards, R.L., Broecker, W.S., Denton, G.H., Kong, K., Wang, Y., Zhang, R., Wang, X., 2009. Ice age terminatinos. Science 326, 248-252.

Cheng, H., Edwards, R.L., Wang, Y., Kong, X, Ming, Y., Kelly, M.J., Wang, X., Gallup, C.D., 2006. A penultimate glacial monsoon record from Hulu Cave and two-phase glacial terminations. Geology, March 2006-34, 217-220.

Clark, G., 1969. World Prehistory: A New Outline, Second Edition, Cambridge, Cambridge University Press.

Cohen, D.J., 1998. The origins of domesticated cereals and the Pleistocene-Holocene transition in East Asia. The Review of Archaeology 19, 22-29. 
Dansgaard, W., Johnsen, S.J., Clausen, H.B., Dahl-Jensen, D., Gundestrup, N.S., Hammer, C.U., Hvidberg, C.S., Stephensen, J.P., Sveinbjornsdottir, A.E., Jouzel, Z., Bond, G., 1993. Evidence for general instability of past climate from a 250-kyr ice-core record. Nature 364, 218-220.

Denton, G.H., Alley, R.B., Comer, G.C., Broecker, W.S., 2005. The role of seasonality in abrupt climate change. Quaternary Science Reviews 24, 1159-1182.

Dillehay, T.D., 2000. The Settlement of the Americas: A new prehistory. New York, Basic Book.

Elston, R., Dong, G., Zhang, D., 2010. Human responses to the Younger Dryas in China. Paper presented at the annual meeting of the Society for American Archaeology, St. Louis.

Faught, M.K., 2008. Archaeological roots of human diversity in the New World: a compilation of accurate and precise radiocarbon ages from earliest sites. American Antiquity 73, 670-698.

Fukusawa, H., 1999. Varved lacustrine sediments in Japan: recent progress. The Quaternary Research 38(3), 237-243.

Gamble, C., 1993. Timewalkers: the prehistory of global colonization. Cambridge, Harvard University Press.

Goebel, T., Waters, M.R., O'Rourke, D.H., 2008. The Late Pleistocene dispersal of modern humans in the Americas. Science 319, 1497-1502.

Grayson, D.K., 1984. Quantitative Zooarchaeology: Topics in the Analysis of Archaeological Faunas. New York, Academic Press.

Habu, J., 2004. Ancient Jomon of Japan. Cambridge, Cambridge University Press. 
Hamilton, M.J., Buchanan, B., 2007. Spatial gradients in Clovis-age radiocarbon dates across North America suggest rapid colonization from the north. Proceedings of the National Academy of Sciences of the United States of America 104, 15625-15630.

Hayashi, K., 1968. Fukui microblade technology and its relationship in Northeast Asia and North America. Arctic Anthropology 5, 128-90.

Hays, J.D., Imbrie, J., Shackleton, N.J., 1976. Variations in the earth' orbit: pacemaker of ice ages. Science 194, 1121-1132.

Hoffecker, J.F., Powers, W.R., Goebel, T., 1993. The colonization of Beringia and the peopling of the New World. Science 259, 46-53.

Igarashi, Y., Oba, T., 2006. Fluctuations in the East Asian monsoon over the last 144ka in the northwest Pacific based on a high-resolution pollen analysis of IMAGES core MD01-2421. Quaternary Science Reviews 25, 1447-1459.

Ikawa-Smith, F., 1976. On ceramic technology in East Asia. Current Anthropology 17, 513-515.

Iwase, A., Hashizume, J., Izuho, M., Takahashi, K., Sato, H., 2010. AMS ${ }^{14} \mathrm{C}$ chronologies of terrestrial mammalian megafauna in the late Late Pleistocene on the Japanese Archipelago. Quarteraire, Hors serié (3), 165-166.

Kanomata, Y., 2007. The human adaptation to the environmental change in East Japan from the end of Pleistocene to the beginning of Holocene Epoch. Miyagi Kōkogaku 9, 1-20. (in Japanese) 
Kawamura, K., Parrenin, F., Lisiecki, L., Uemura, R., Vimeux, F., Severinghaus, J., Hutterli, M.A., Nakazawa, T., Aoki, S., Jouzel, J., Raymo, M.E., Matsumoto, K., Nakata, H., Motoyama, H., Fujita, S., Goto-Azuma, K., Fujii, Y., Watanabe, O., 2007. Northern Hemisphere forcing of climate cycles in Antarctica over the past 360,000 years. Nature 448, 912-916.

Keally, C.T., Taniguchi, Y., Kuzmin, Y.V., 2003. Understanding the beginnings of pottery technology in Japan and neighboring East Asia. The Review of Archaeology 24, 3-14.

Keigwin, L.D., Gorbarenko, S.A., 1992. Sea level, surface salinity of the Japan Sea, and the Younger Dryas event in the northwestern Pacific Ocean. Quaternary Research 37, 346-360.

Kitagawa, H., van der Plicht, J., 1998. A 40,000 year varve chronology from lake Suigetsu, Japan: extension of the radiocarbon calibration curve. Radiocarbon 40, 505-516.

Kobayashi, K., 2008. The Dates of the Incipient Pit House on the Japanese Archipelago. Hakumon Koko Ronso II, 1-28. (in Japanese)

Kudo, Y., 2004. Reconsidering the geochronological and archaeological framework of the late Pleistocene-early Holocene transition on the Japanese Islands. In: Tergerger, T., Eriksen (Eds.), Internationale Archaologie - Arbeitsgemeinschaft. Tagung, Smposium, Kongress 5, pp. 253-268.

Kumon, F., Kawai, S., Iuchi, Y., 2009. High-resolution reconstruction of paleoclimate during the last 72ka on the basis of the drilled sediments from Lake Nojiri, central Japan. Palaeolithic Research 6, 1-10. (in Japanese with English abstract) 
Kuzmin, Y.V., 2006. Chronology of the earliest pottery in East Asia: progress and pitfalls. Antiquity 80, 362-371.

Leonard, R., Jones, G.T., (Eds.), 1989. Quantifying Diversity in Archaeology. Cambridge, Cambridge University Press.

Matsui, A., Kanehara, M., 2006. The question of prehistoric plan husbandry during the Jomon period in Japan. Word Archaeology 38, 259-273.

Nagasaki Broad of Education, 1986. Takano Site. Nagasaki Broad of Education, Nagasaki Prefecture. (in Japanese)

Nakagawa, T., Kitagawa, H., Yasuda, Y., Tarasov, P.E., Gotanda, K., Sawai, Y., 2005. Pollen/event stratigraphy of the varved sediments of Lake Suigetsu, central Japan from 15,701 to 10,217 SG vyr BP (Suigetsu varve years before present): description, interpretation, and correlation with other regions. Quaternary Science Reviews 24, 1691-1701.

Nakamura, T., Taniguchi, Y., Tsuji, S., Oda, H. 2001. Radiocarbon dating of charred residues on the earliest pottery in Japan. Radiocarbon 43, 1129-1138.

Nakazawa, Y., Izuho, M., Takakura, J., Yamada, S., 2005. Toward an understanding of technological variability in microblade assemblages in Hokkaido, Japan. Asian Perspectives 44, 276-292.

Niimi, N., 2010. Diachronic change in birds and mammalian species. In: Y. Kosugi, Y. Taniguchi, Y. Nishida, W. Mizunoe, and K. Yano. (Eds.), The Relationships between Humans and Animals, Doseisha, pp. 131-148. (in Japanese) 
Nishida, M., 1986. The Sedentary Revolution. Tokyo, Shinyosha. (in Japanese)

Nishimoto, T., 1991. Wild boar and deer hunting in the Jomon period. Kodai 92, 114-132. (in Japanese)

Nishino-omote City Broad of Education, 2004. Kigano Site. Nishino-omote City Broad of Education, Kagoshima Prefecture. (in Japanese)

Nunn, P., Keally, C.T., King, C., Wijaya, J., Cruz, R., 2006. Human responses to coastal change in the Asia-Pacific region. In: Harvey, N. (Ed.), Global Change and Integrated Coastal Management: the Asia-Pacific Region. Springer, Dordrecht, pp. 117-162.

Onbe, S., 2007. The results of projects. In: Kobayashi, K. (Ed.), Study for the Calibrated AMS ${ }^{14} \mathrm{C}$ Chronology of the Early Part of Jomon Period in Eastern Japan. The Report of Grants-inAid for Scientific Research (C), 8-45. (in Japanese)

Pearson, R., 2006. Jomon hot spot: increasing sedentism in south-western Japan in the Incipient Jomon (14,000-9250 cal. BC) and Earliest Jomon (9250-5300 cal. BC) periods. World Archaeology 38, 239-258.

Rice, P.M., 1999. On the origins of pottery. Journal of Archaeological Method and Theory 6, 154.

Rogers, R.A., Rogers, L.A., Hoffmann, R.S., Martin, L.D., 1991. Native American biological diversity and biogeographic influence of Ice Age refugia. Journal of Biogeography 18, 623630. 
Sato, H., Izuho, M., Morisaki, K., 2010. Human cultures and environmental changes in the Pleistocene/Holocene transition in the Japanese Archipelago. Manuscript submitted to Quaternary International.

Serizawa, C., 1976. The stone age of Japan. Asian Perspectives 19, 1-14.

Shinto, K., 1999. The peculiarity of the southern Kyushu: with a special reference to the Initial Jomon. Kikan Kokogaku (Quarterly Archaeology) 69, 18-22. (in Japanese)

Shizuoka Prefectural Research Institute for Buried Cultural Properties, 2000. Ikeda B Site. Shizuoka Prefecture. (in Japanese)

Steele, J., Adams, J., Sluckin, T., 1998. Modelling Paleoindian dispersals. World Archaeology 30, 286-305.

Stephens, D.W., Krebs, J.R. 1986. Foraging Theory. Princeton University Press, Princeton.

Straus. L.G., 1996. The world at the end of the Last Ice Age: The archaeology at the PleistoceneHolocene transition. In: L.G. Straus, B.V. Eriksen, J.M. Erlandson, D.R. Yesner (Eds.), Humans at the End of the Ice Age, Plenum Press, New York, pp. 3-9.

Stuiver, M., Grootes, P.M., Braziunas, T.F., 1995. The GISP $\delta^{18} \mathrm{O}$ climate record of the past 16,500 years and the role of the sun, ocean, and volcanoes. Quaternary Research 44, 341-354.

Sugihara, S., Serizawa, C., 1957. Shell Mounds of the Earliest Jomon Culture at Natsushima. Faculty of Literature, Meiji University, Tokyo. (in Japanese with English abstract)

Surovell, T. A., 2000. Early Paleoindian women, children, mobility, and fertility. American Antiquity 65, 493-508. 
Tada, R., 1999. Late Quaternary paleoceanography of the Japan Sea. The Quaternary Research $38(3), 216-222$.

Takahara, H., Igarashi, Y., Hayashi, R., Kumon, F., Liew, P.M., Yamamoto, M., Kawai, S., Oba, T., Irino, T., 2010. Millennial-scale variability in vegetation records from the East Asian Islands: Taiwan, Japan and Sakhalin. Quaternary Science Reviews 29, 2900-2917.

Takahashi, K., Izuho, M., 2010. Formative history of terrestrial fauna on the Japanese Islands during the Plio-Pleistocene. Manuscript in possession of authors.

Wang, Y.J., Cheng, H., Edwards, R.L., An, Z.S., Wu, Y.J., Shen, C.-C., Dorale, J.A., 2001. A high-resolution absolute-dated Late Pleistocene monsoon record from Hulu Cave, Chana. Science 294, 2345-2348.

Wang, Y., Cheng, H., Edwards, R.L., Kong, X., Shao, X., Chen, S, Wu, J., Jiang, X., Wang, X., An, Z., 2008. Millennial- and orbital-scale changes in the East Asian monsoon over the past 224,000 years. Nature 451, 1090-1093.

Wobst, H.M., 1974. Boundary conditions for Palaeolithic social systems: a simulation approach. American Antiquity 39, 147-178.

Yasuda, Y., 2000. The Emergence of Large River Civilizations. Tokyo, Kadokawa Publish. (in Japanese)

Yuan, D., Cheng, H., Edwards, R.L., Dykoski, C.A., Kelly, M.J., Zhang, M., Qing, J., Lin, Y., Wang, Y., Wu, J., Dorale, J.A., An, Z., Cai, Y., 2004. Timing, duration, and transitions of the Last Interglacial Asian Monsoon. Science 304, 575-578. 


\section{Captions}

Fig. 1. A chronological framework for Paleolithic and Jomon with sea-level changes in Japan (modified from Figure 2.8 in Habu 2004: 44).

Fig. 2. The frequency of sites among the three contiguous chronozones (i.e., Bølling-Allerød, Younger Dryas, Preboreal) at the Pleistocene/Holocene transition.

Fig. 3. Number of archaeological sites by latitudes, compared among the Bølling/Allerød, Younger Dryas, and Prebreal.

Fig. 4. Map of the Japanese Archipelago, showing locations of the Late Glacial sites by different periods

Fig. 5. Lithic artifacts and ceramic vessels compared among regions through chronozones. Regions are sorted by Kyushu, Kanto/Chubu/Tokai/Western Honoshu, and Hokkaido/Tohoku, from south to north.

Table 1. List of late Late Glacial sites in the Japanese Archipelago, with regions, sampled locations, laboratory numbers, methods, materials to be dated, $\delta{ }^{13} \mathrm{C}$ values, radiocarbon dates (B.P.), upper and lower limits of confidence around the mean calibrated age, and references.

Table 2. Summary of Late Glacial sites with determined chronozones. Sites are ordered by region from north. Number of ${ }^{14} \mathrm{C}$ dates from a site, and number of groups that show continuous range of dates. "Chronozone for dominant dates" signifies the chronozone in which majority of dates from the site are encompassed. Chronozone represents the determined chronozone of the site.

Table 3. Median and maximum NISP for pottery assemblages compared among the Bølling/Allerød, Younger Dryas, and Prebreal. 


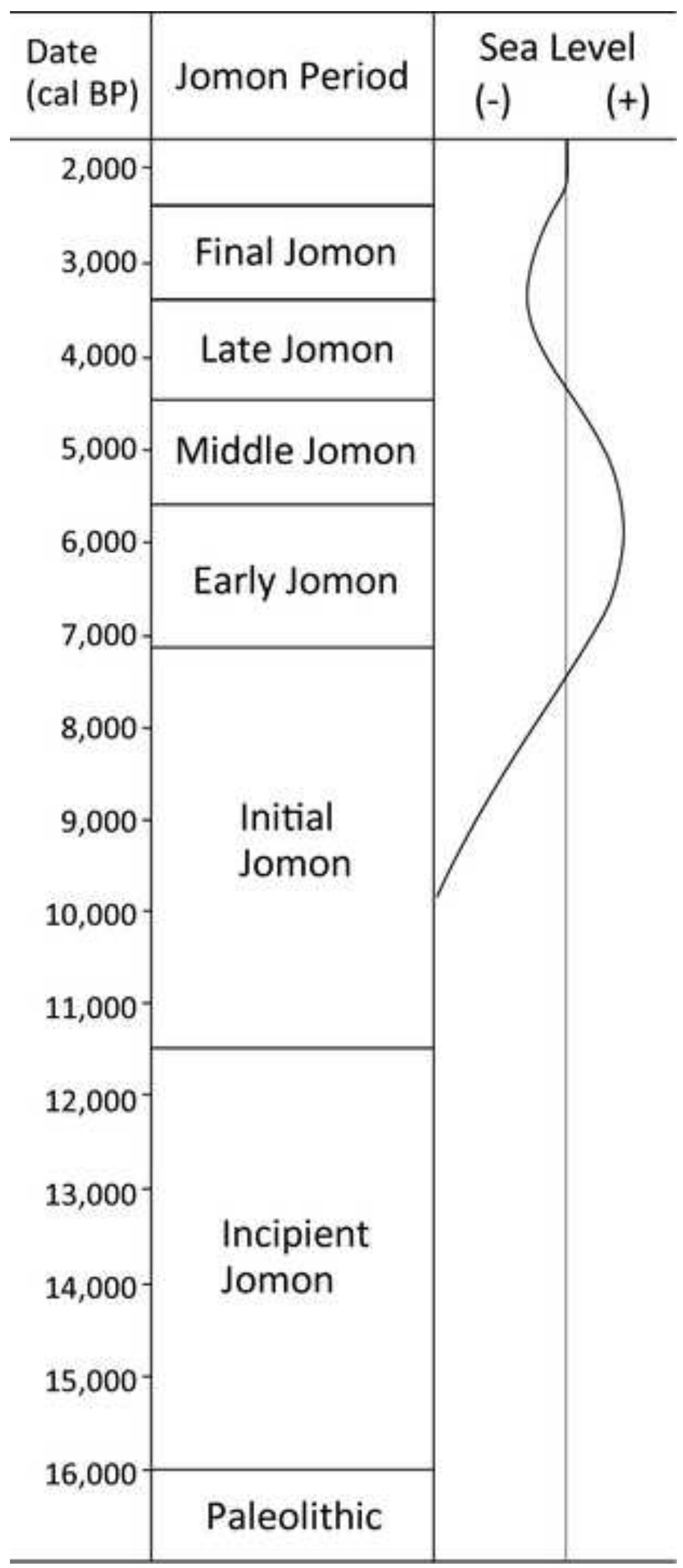




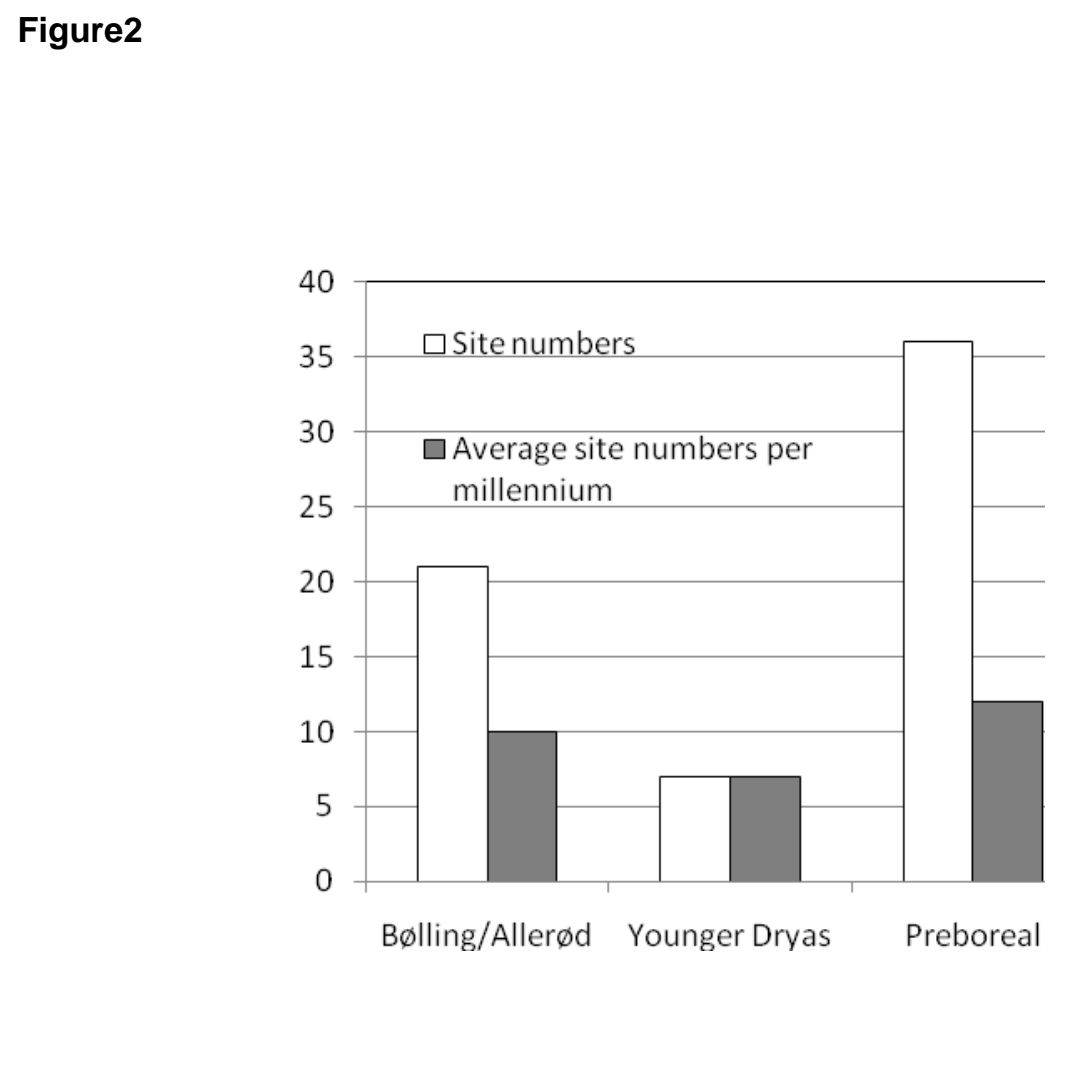

Fig. 2.

Figure2

2

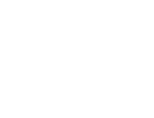

$(2+2$
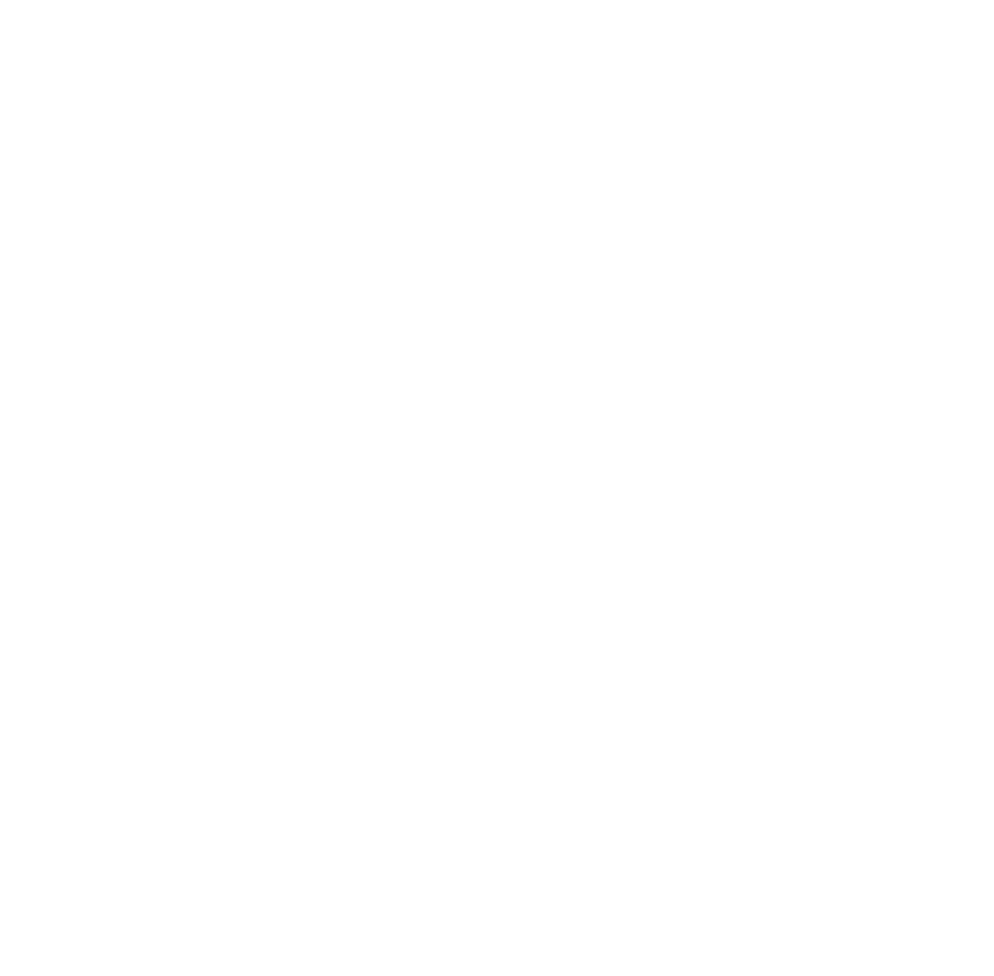

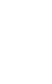

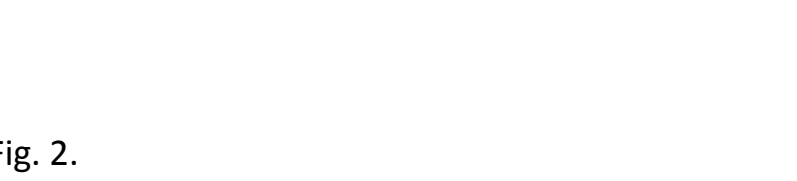

.

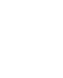

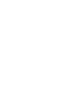

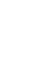

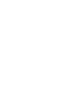

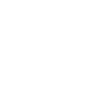

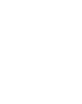

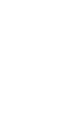

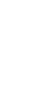
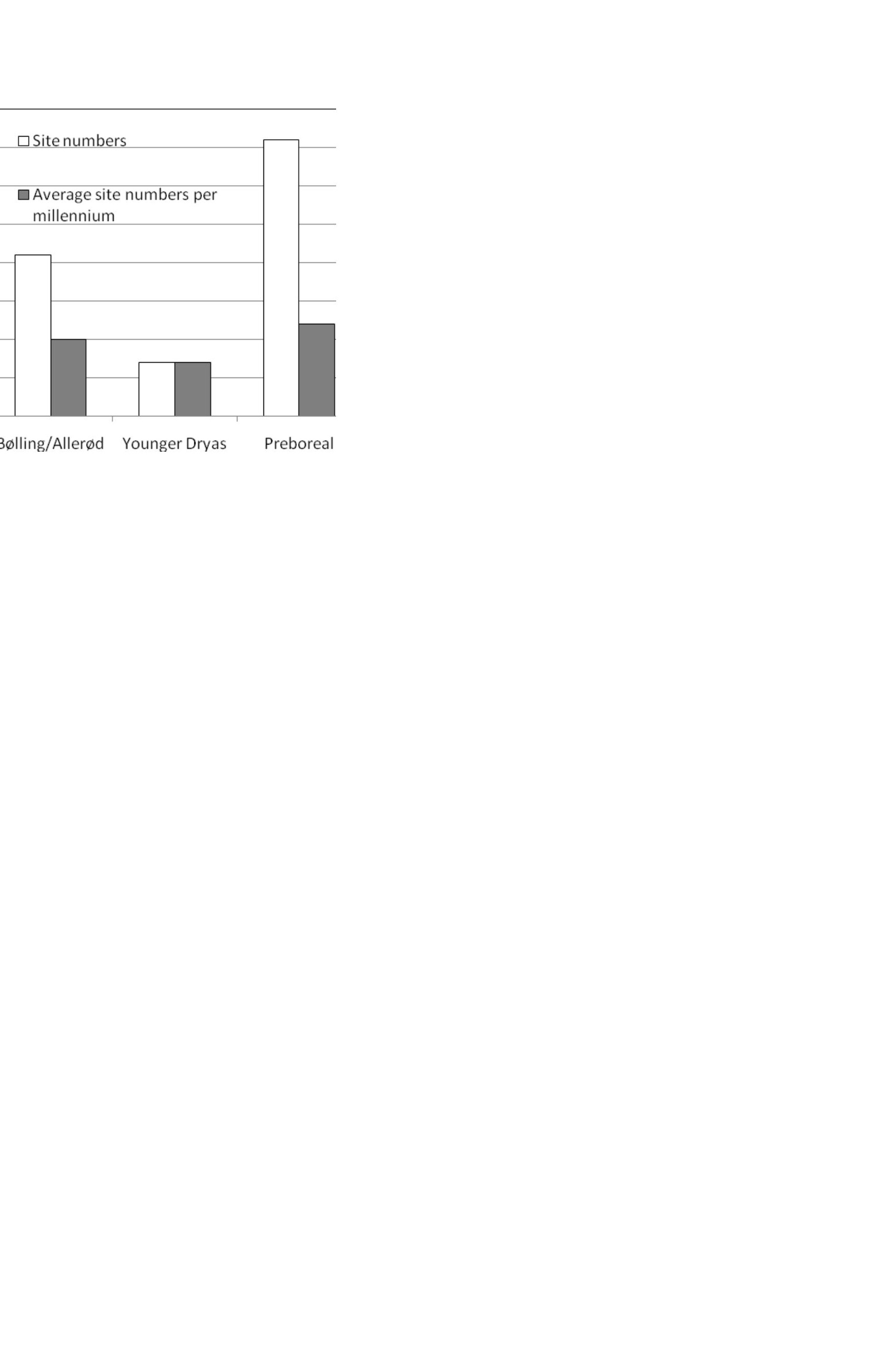


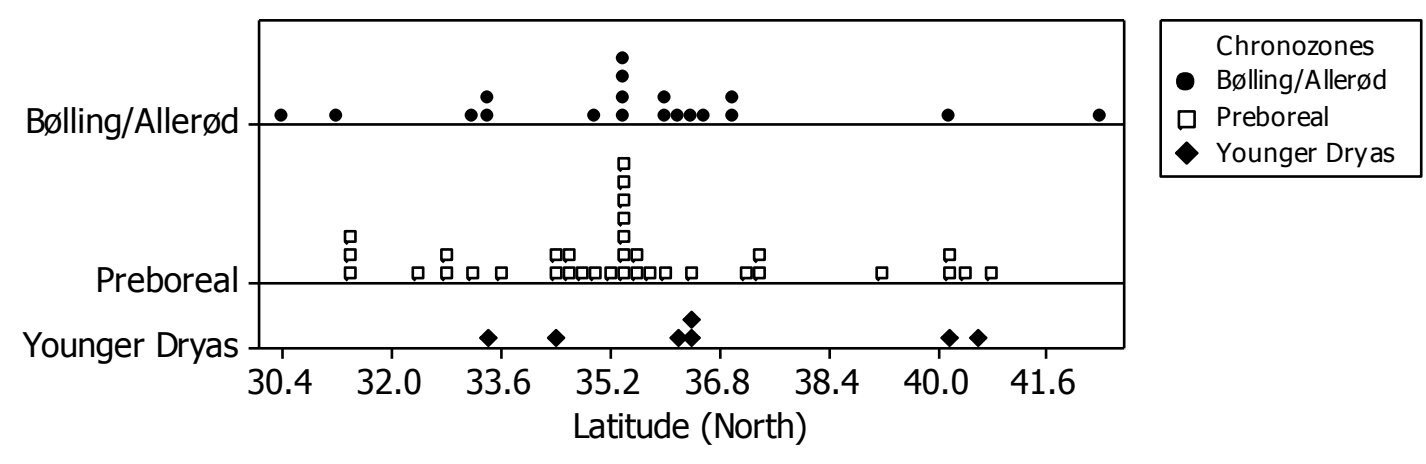

Fig. 3. Bøllin
Younc
Fig. 3.

\begin{tabular}{ll} 
Chronozones \\
Bølling/Allerød \\
Preboreal \\
Younger Dryas \\
\hline
\end{tabular}

\begin{tabular}{ll} 
Chronozones \\
Bølling/Allerød \\
Preboreal \\
Younger Dryas \\
\hline
\end{tabular}

\begin{tabular}{ll} 
Chronozones \\
Bølling/Allerød \\
Preboreal \\
Younger Dryas \\
\hline
\end{tabular} Latitude (North)

Fig. 3.

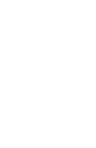

.

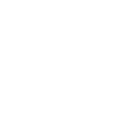

.

.
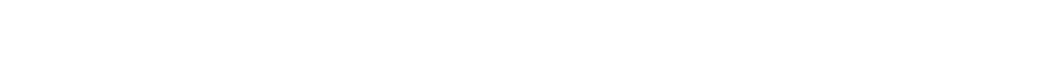

.

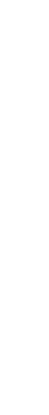




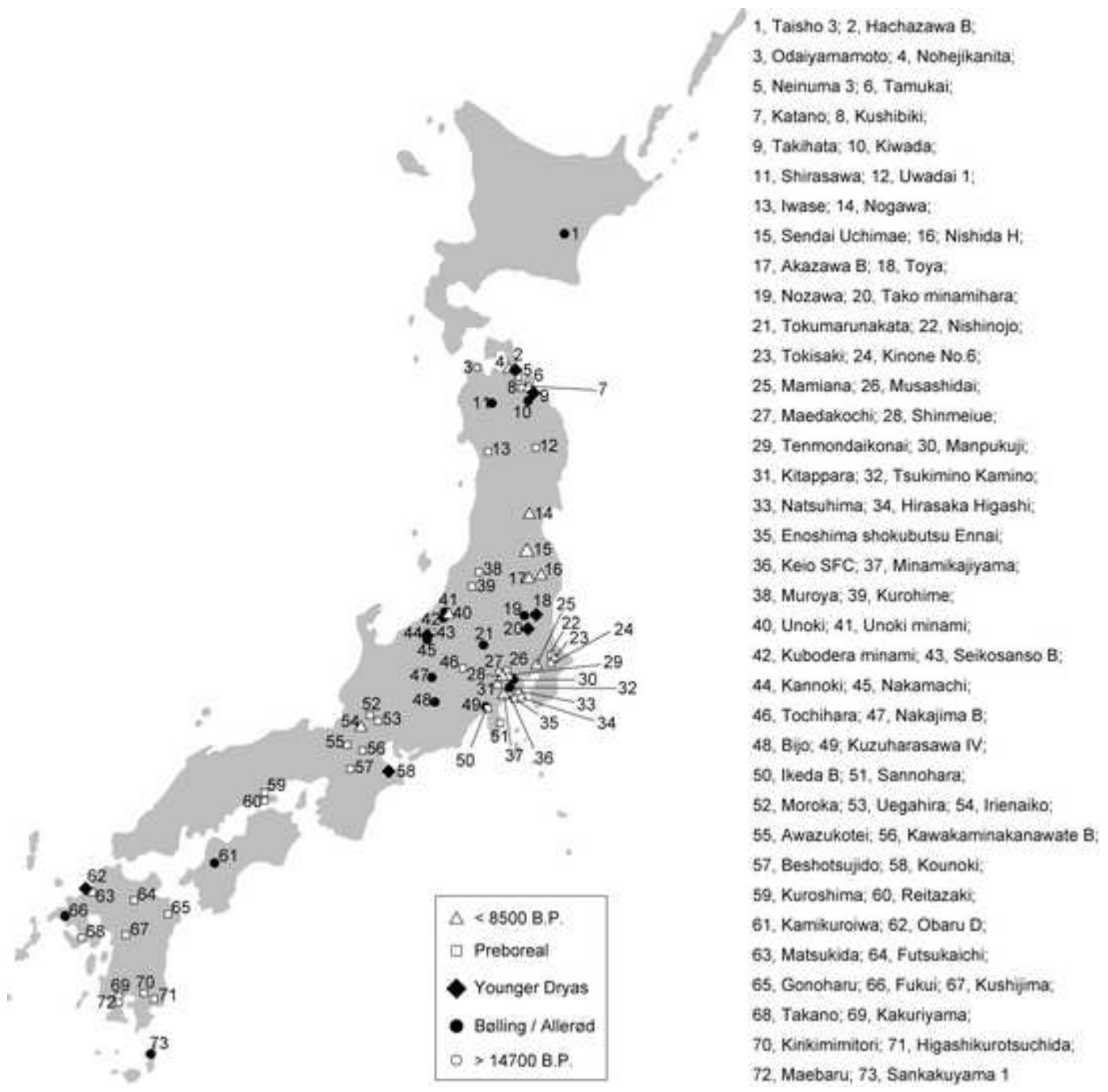




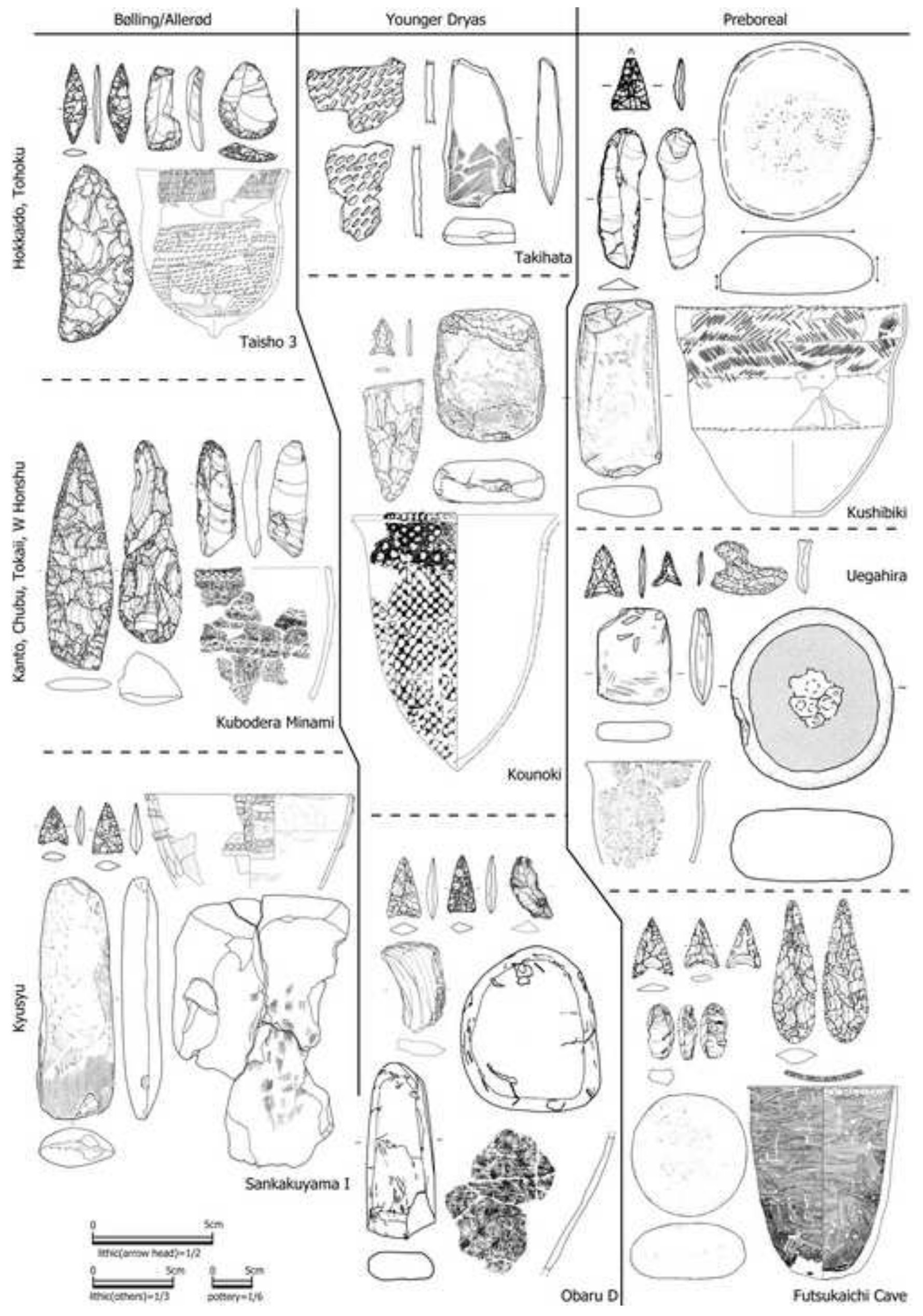




\begin{tabular}{|c|c|c|c|c|c|c|c|c|c|c|}
\hline Site & Region & Sampled location & Lab. No. & Method & Material & $\delta 13 \mathrm{C}$ & $\begin{array}{c}\text { 14C Age } \\
\text { (BP) }\end{array}$ & $\pm 1 \sigma$ & $\begin{array}{l}\text { Calibrated Date } \\
\text { cal. BP }(68.2 \%)\end{array}$ & $\begin{array}{l}\text { Calibrated Date } \\
\text { cal. BP }(68.2 \%)\end{array}$ \\
\hline Taisho 3 & Hokkaido & District 3-17, Layer Vb-VIII & Beta-194626 & AMS & CAP & -23.5 & 12380 & 40 & 14490 & 14160 \\
\hline Taisho 3 & Hokkaido & District 3-17, Layer Vb-VIII & Beta-194627 & AMS & CAP & -24 & 12200 & 40 & 14120 & 14000 \\
\hline Taisho 3 & Hokkaido & District 3-17, Layer Vb-VIII & Beta-194628 & AMS & CAP & -23.7 & 12330 & 40 & 14350 & 14100 \\
\hline Taisho 3 & Hokkaido & District 3-16, Layer Vb-VIII & Beta-194629 & AMS & CAP & -22.6 & 12420 & 40 & 14590 & 14240 \\
\hline Taisho 3 & Hokkaido & District 3-16, Layer Vb-VIII & Beta-194630 & AMS & CAP & -23.4 & 12180 & 40 & 14100 & 13980 \\
\hline Taisho 3 & Hokkaido & District 3-16, Layer Vb-VIII & Beta-194631 & AMS & CAP & -23.3 & 12100 & 40 & 14020 & 13880 \\
\hline Taisho 3 & Hokkaido & Loam on the top of river gravels & IAAA-41603 & AMS & CAP & -21.56 & 12290 & 60 & 14270 & 13880 \\
\hline Taisho 3 & Hokkaido & Loam on the top of river gravels & IAAA-41604 & AMS & CAP & -23.24 & 12330 & 60 & 14420 & 14090 \\
\hline Taisho 3 & Hokkaido & Loam on the top of river gravels & IAAA-41605 & AMS & CAP & -22.08 & 12120 & 50 & 14050 & 13890 \\
\hline Taisho 3 & Hokkaido & Loam on the top of river gravels & IAAA-41606 & AMS & CAP & -21.74 & 12470 & 50 & 14720 & 14300 \\
\hline Taisho 3 & Hokkaido & Loam on the top of river gravels & IAAA-41607 & AMS & CAP & -22.47 & 12160 & 60 & 14100 & 13940 \\
\hline Kiwada & Tohoku & Pit house No.2, Layer 2 & Beta-148515 & AMS & $\mathrm{Ch}$ & -23.8 & 12360 & 50 & 14460 & 14130 \\
\hline Odaiyamamoto I & Tohoku & Layer III & Beta-125550 & AMS & $\mathrm{CW}$ & -26.1 & 12360 & 70 & 14570 & 14540 \\
\hline Odaiyamamoto I & Tohoku & Layer IV upper most & NUTA-6506 & AMS & CAP & -29.6 & 12680 & 140 & 15200 & 14650 \\
\hline Odaiyamamoto I & Tohoku & Layer III lower & NUTA-6507 & AMS & CAP & -30.5 & 13030 & 170 & 15700 & 15100 \\
\hline Odaiyamamoto I & Tohoku & Layer III bottom & NUTA-6509 & AMS & CAP & N/A & 12720 & 160 & 15300 & 14650 \\
\hline Odaiyamamoto I & Tohoku & Layer IV & NUTA-6510 & AMS & CAP & N/A & 13780 & 170 & 16700 & 16100 \\
\hline Odaiyamamoto I & Tohoku & Layer III & NUTA-6515 & AMS & CAP & N/A & 13210 & 160 & 15950 & 15350 \\
\hline Kushibiki & Tohoku & Pit No. 4 & Beta-113349 & AMS & $\mathrm{Ch}$ & -30.5 & 10030 & 50 & 11630 & 11390 \\
\hline Takihata & Tohoku & Cobble concentration & Beta-138898 & AMS & $\mathrm{Ch}$ & -25.3 & 10260 & 40 & 12100 & 11970 \\
\hline Hachazawa B & Tohoku & Bottom of the pit & Gak-9936 & Beta & N/A & N/A & 10140 & 300 & 12350 & 11250 \\
\hline Iwase & Tohoku & SN08 Burnt sediment & Gak-15803 & Beta & $\mathrm{Ch}$ & N/A & 8430 & 130 & 9550 & 9280 \\
\hline Iwase & Tohoku & SN16 Burnt sediment & Gak-15804 & Beta & $\mathrm{Ch}$ & N/A & 7460 & 170 & 8220 & 8050 \\
\hline Iwase & Tohoku & SQ77 cobble-filled hearth & Gak-17801 & Beta & $\mathrm{Ch}$ & N/A & 10050 & 50 & 11580 & 11400 \\
\hline Iwase & Tohoku & SXQ60 Hearth1 & Gak-17802 & Beta & $\mathrm{Ch}$ & N/A & 10910 & 170 & 13070 & 12790 \\
\hline Uwadai 1 & Tohoku & Pit house RA 02 & Beta-161171 & AMS & $\mathrm{Ch}$ & -26.1 & 9540 & 40 & 11070 & 10950 \\
\hline Uwadai 1 & Tohoku & Pit house RA 03 & Beta-161172 & AMS & $\mathrm{Ch}$ & -27.6 & 9540 & 40 & 11070 & 10950 \\
\hline Uwadai 1 & Tohoku & Pit house RA 02 & Beta-183451 & AMS & CAP & -25.1 & 4450 & 40 & 5070 & 4970 \\
\hline Uwadai 1 & Tohoku & Pit house RA01 & IAAA-31108 & AMS & CAP & $-26.0 \pm 0.9$ & 9850 & 50 & 11275 & 11205 \\
\hline Nogawa & Tohoku & Pit 1 & NUTA-3540 & AMS & $\mathrm{CW}$ & N/A & 5940 & 90 & 6890 & 6660 \\
\hline Nogawa & Tohoku & Pit 1 Fill1 & NUTA-3550 & AMS & $\mathrm{CW}$ & N/A & 3320 & 70 & 3640 & 3470 \\
\hline Nogawa & Tohoku & Pit 1 Fill 1 \& 2 & NUTA-3551 & AMS & $\mathrm{CW}$ & N/A & 3710 & 80 & 4160 & 3920 \\
\hline Nogawa & Tohoku & Pit 2 & & AMS & $\mathrm{CW}$ & N/A & $\begin{array}{l}\text { unable to } \\
\text { date }\end{array}$ & & N/A & N/A \\
\hline Nogawa & Tohoku & Trench No.6 Layer 4, Ro & NUTA-3552 & AMS & $\mathrm{CW}$ & N/A & 3730 & 80 & 4180 & 3970 \\
\hline Nogawa & Tohoku & Trench No. 6 Layer 4, Mu & NUTA-3553 & AMS & $\mathrm{CW}$ & N/A & 3160 & 80 & 3480 & 3320 \\
\hline $\begin{array}{c}\text { Sendai Uchimae } \\
\text { Loc. A }\end{array}$ & Tohoku & Grid Q-7 & NUTA-603 & AMS & $\mathrm{Ch}$ & N/A & 6930 & 100 & 7860 & 7670 \\
\hline $\begin{array}{c}\text { Sendai Uchimae } \\
\text { Loc. F }\end{array}$ & Tohoku & Pit house 2 & NUTA-604 & AMS & $\mathrm{Ch}$ & N/A & 9750 & 100 & 11270 & 11070 \\
\hline $\begin{array}{l}\text { Sendai Uchimae } \\
\text { Loc. F }\end{array}$ & Tohoku & Pit house 2 & NUTA-605 & AMS & $\mathrm{Ch}$ & N/A & 9590 & 70 & 11040 & 10780 \\
\hline Nohejikanita & Tohoku & Cultural layer & Beta-173155 & AMS & CAP & -23.7 & 6600 & 40 & 7240 & 7120 \\
\hline Tamukai & Tohoku & & Beta-188189 & AMS & CAP & -25.4 & 8530 & 50 & 9250 & 9080 \\
\hline Shirasawa & Tohoku & N/A & Beta-163737 & Beta & CAP & -26 & 9410 & 50 & 10700 & 10580 \\
\hline Shirasawa & Tohoku & N/A & Beta-163735 & Beta & CAP & -24.8 & 9080 & 60 & 10285 & 10185 \\
\hline Shirasawa & Tohoku & N/A & Beta-163736 & Beta & CAP & -25.5 & 9030 & 60 & 10250 & 10160 \\
\hline Shirasawa & Tohoku & N/A & Beta-163738 & Beta & CAP & -25.1 & 9020 & 40 & 10230 & 10185 \\
\hline Nishida $\mathrm{H}$ & Tohoku & Pit house S108, floor & Beta-190355 & AMS & CAP & -25.8 & 6950 & 40 & 7495 & 7415 \\
\hline Nishida $\mathrm{H}$ & Tohoku & District V19, Layer IV & MTC-04343 & AMS & CAP & -24.3 & 6405 & 45 & 6950 & 6810 \\
\hline Akazawa B & Tohoku & Pit 81 & Beta-158778 & AMS & $\mathrm{Ch}$ & -25.9 & 7190 & 40 & 7695 & 7600 \\
\hline Akazawa B & Tohoku & Pit 81, Layer 3 & Beta-158779 & AMS & $\mathrm{Ch}$ & -26.1 & 7150 & 50 & 7665 & 7570 \\
\hline Akazawa B & Tohoku & Pit 25, Layer 2 & Beta- 158780 & AMS & $\mathrm{Ch}$ & -26.6 & 7070 & 40 & 7590 & 7505 \\
\hline Akazawa B & Tohoku & Pit 11 , Layer 2 & Beta-158781 & AMS & $\mathrm{Ch}$ & -24.4 & 4230 & 50 & 4410 & 4250 \\
\hline Katano & Tohoku & Layer IVa & MTC-08492 & AMS & CAP & & 5730 & 45 & 6100 & 5950 \\
\hline Neinuma(3) & Tohoku & Q10 grid, Layer VI & MTC-08494 & AMS & CAP & & 8520 & 60 & 9250 & 9060 \\
\hline Unoki Minami & Chubu & N/A & Beta-136739 & AMS & CAP & -24.8 & 11000 & 50 & 12965 & 12875 \\
\hline Unoki Minami & Chubu & N/A & Beta-136740 & AMS & CAP & -24.5 & 11040 & 50 & 13030 & 12900 \\
\hline Unoki Minami & Chubu & N/A & Beta-136741 & AMS & CAP & -25.2 & 11130 & 50 & 13090 & 12970 \\
\hline Unoki Minami & Chubu & N/A & Beta-136742 & AMS & CAP & -21.2 & 11630 & 50 & 13560 & 13390 \\
\hline Unoki & Chubu & N/A & Beta-156886 & AMS & $\mathrm{Ch}$ & -24.7 & 2960 & 40 & 3210 & 3110 \\
\hline Kubodera Minami & Chubu & Layer 2 Lower & Beta-136743 & AMS & CAP & -24.9 & 12280 & 50 & 14220 & 14050 \\
\hline Kubodera Minami & Chubu & Layer 2 Lower & Beta-136744 & AMS & CAP & -24.8 & 12420 & 50 & 14600 & 14230 \\
\hline Kubodera Minami & Chubu & Layer 2 & Beta-136745 & AMS & CAP & -23.8 & 12490 & 60 & 14830 & 14380 \\
\hline Kubodera Minami & Chubu & Layer 2 & Beta-136746 & AMS & CAP & -23.6 & 12620 & 50 & 15020 & 14730 \\
\hline Kubodera Minami & Chubu & Layer 35 & Beta- 136747 & AMS & CAP & -23.9 & 12510 & 40 & 14870 & 14480 \\
\hline Kubodera Minami & Chubu & Layer 33 & Beta-140494 & AMS & CAP & -25.2 & 12520 & 50 & 14890 & 14480 \\
\hline Kubodera Minami & Chubu & ? & Beta-140495 & AMS & CAP & -26.5 & 12630 & 50 & 15030 & 14750 \\
\hline Muroya & Chubu & Layer VII (Lower incipient) & Beta-156887 & AMS & $\mathrm{Ch}$ & -26.9 & 7850 & 50 & 8720 & 8610 \\
\hline Shimomouchi & Chubu & Charcoal Con 1 & NUTA-1515 & AMS & $\mathrm{Ch}$ & & 16250 & 180 & 19560 & 19160 \\
\hline $\begin{array}{l}\text { Cultural Laver II } \\
\text { Kannoki }\end{array}$ & Chubu & SK37 fill & - & & $?$ & & 10260 & 140 & 12400 & 11750 \\
\hline Kannoki & Chubu & SK38 fill & - & & ? & & 10150 & 140 & 12100 & 11400 \\
\hline Kannoki & Chubu & SK63 & - & & ? & & 10000 & & N/A & N/A \\
\hline Kannoki & Chubu & SK35 & - & & $?$ & & 9600 & & N/A & N/A \\
\hline Kannoki loc.H5 & Chubu & N/A & Nuta2-6883 & AMS & CAP & -22.8 & 12360 & 50 & 14460 & 14130 \\
\hline Kannoki loc.H5 & Chubu & N/A & Nuta2-6884 & AMS & CAP & -24.6 & 12490 & 50 & 14820 & 14390 \\
\hline Kannoki loc.H5 & Chubu & N/A & Nuta2-6885 & AMS & CAP & -25.8 & 12350 & 50 & 14440 & 14120 \\
\hline Kannoki loc.H5 & Chubu & N/A & Nuta2-6886 & AMS & CAP & -42.4 & 11460 & 70 & 13380 & 13240 \\
\hline Kannoki loc.H5 & Chubu & Layer III & PLD-1844 & AMS & CAP & -25 & 13010 & 110 & 15560 & 15160 \\
\hline Kannoki loc.H5 & Chubu & Layer III & PLD-1845 & AMS & CAP & -24.8 & 12870 & 110 & 15370 & 15010 \\
\hline Nakajima B & Chubu & Pottery Con No.3 & I-13767 & Beta & $\mathrm{Ch}$ & & 12460 & 310 & 15000 & 14050 \\
\hline Nakamachi BP5a & Chubu & BP5a, Pottery Con & IAAA-40496 & AMS & $\mathrm{Ch}$ & -30.6 & 11990 & 60 & 13920 & 13770 \\
\hline
\end{tabular}




\begin{tabular}{|c|c|c|c|c|}
\hline Region & Site & $\begin{array}{c}\text { Number of } \\
\text { dates }\end{array}$ & $\begin{array}{c}\text { Number of } \\
\text { groups }\end{array}$ & Chronozone for dominant dates \\
\hline Hokkaido & Taisho 3 & 11 & 1 & $\overline{\text { Bølling/Allerød }}$ \\
\hline Tohoku & Kiwada & 1 & 1 & Bølling/Allerød \\
\hline Tohoku & Odaiyamamoto I & 3 & 2 & $>14700$ B.P. \\
\hline Tohoku & Kushibiki & 1 & 1 & Preboreal \\
\hline Tohoku & Takihata & 1 & 1 & Younger Dryas \\
\hline Tohoku & Hachazawa B & 1 & 1 & Younger Dryas \\
\hline Tohoku & Iwase & 4 & 4 & Preboreal \\
\hline Tohoku & Uwadai 1 & 4 & 3 & Preboreal \\
\hline Tohoku & Nogawa & 5 & 4 & $<8500$ B.P. \\
\hline Tohoku & Sendai Uchimae loc. A & 1 & 1 & $<8500$ B.P. \\
\hline Tohoku & Sendai Uchimae loc. F & 2 & 1 & Preboreal \\
\hline Tohoku & Nohejikanita & 1 & 1 & < 8500 B.P. \\
\hline Tohoku & Tamukai & 1 & 1 & Preboreal \\
\hline Tohoku & Shirasawa & 4 & 2 & Bølling/Allerød \\
\hline Tohoku & Akazawa B & 4 & 4 & < 8500 B.P. \\
\hline Tohoku & Katano & 1 & 1 & < 8500 B.P. \\
\hline Tohoku & Neinuma(3) & 1 & 1 & Preboreal \\
\hline Tohoku & Nishida H & 2 & 1 & < 8500 B.P. \\
\hline Chubu & Bijo & 3 & 1 & Bølling/Allerød \\
\hline Chubu & Kannoki & 2 & 1 & Younger Dryas \\
\hline Chubu & Kannoki loc.H5 & 4 & 2 & Bølling/Allerød \\
\hline Chubu & Kubodera Minami & 5 & 2 & Bølling/Allerød \\
\hline Chubu & Kurohime Cave & 7 & 5 & Preboreal \\
\hline Chubu & Muroya & 2 & 1 & Preboreal \\
\hline Chubu & Nakajima B & 1 & 1 & Bølling/Allerød \\
\hline Chubu & Nakamachi BP4, 5a & 10 & 2 & Bølling/Allerød \\
\hline Chubu & Nakamachi BP5a & 1 & 1 & Bølling/Allerød \\
\hline Chubu & Seikosanso B & 3 & 2 & Preboreal \\
\hline Chubu & Tochihara & 1 & 1 & Preboreal \\
\hline Chubu & Unoki & 1 & 1 & < 8500 B.P. \\
\hline Chubu & Unoki Minami & 4 & 2 & Bølling/Allerød \\
\hline N Kanto & Nozawa & 9 & 2 & Bølling/Allerød \\
\hline N Kanto & Saishikada Nakajima (B) & 3 & 3 & Bølling/Allerød, Younger Dryas, \& Preboreal \\
\hline N Kanto & Tako Minamihara & 2 & 1 & Younger Dryas \\
\hline N Kanto & Tokumaru Nakata & 5 & 2 & Bølling/Allerød \\
\hline N Kanto & Toya & 2 & 1 & Younger Dryas \\
\hline S Kanto & Enoshima Shokubutu Ennai & 2 & 1 & Preboreal \\
\hline S Kanto & Hirasaka Higashi & 1 & 1 & Preboreal \\
\hline S Kanto & Shinmeiue & 3 & 1 & $<8500$ B.P. \\
\hline S Kanto & Juno & 4 & 2 & Bølling/Allerød \& Younger Dryas \\
\hline S Kanto & Keio SFC & 8 & 6 & Preboreal \\
\hline S Kanto & Kinone No.6 & 1 & 1 & Preboreal \\
\hline S Kanto & Kitappara & 1 & 1 & Preboreal \\
\hline S Kanto & Maeda Kochi & 1 & 1 & > 14700 B.P. \\
\hline S Kanto & Mamiana & 5 & 3 & $<8500$ B.P. \\
\hline S Kanto & Manpukuji No.1 & 1 & 1 & Bølling/Allerød \\
\hline S Kanto & Minami Kajiyama & 1 & 1 & < 8500 B.P. \\
\hline S Kanto & Musashidai & 2 & 2 & Preboreal \\
\hline S Kanto & Natsushima & 2 & 1 & Preboreal \\
\hline S Kanto & Nishinojo & 2 & 1 & Preboreal \\
\hline S Kanto & Tenmondai Konai & 1 & 1 & Preboreal \\
\hline S Kanto & Tokisaki (Trench 9) & 3 & 1 & Preboreal \\
\hline S Kanto & Tsukimino Kamino Loc.1 & 2 & 1 & Bølling/Allerød \\
\hline S Kanto & Tsukimino Kamino Loc.2 & 1 & 1 & Bølling/Allerød \\
\hline Tokai & Ikeda B & 5 & 2 & Preboreal \\
\hline Tokai & KamikawanakanawateA & 1 & 1 & Preboreal \\
\hline Tokai & Kounoki & 11 & 3 & Younger Dryas \\
\hline Tokai & Kuzuharazawa IV & 4 & 2 & Bølling/Allerød \\
\hline Tokai & Moroka & 17 & 2 & Preboreal \\
\hline Tokai & Ogakubo & 4 & 4 & Bølling/Allerød, Younger Dryas, \& Preboreal \\
\hline Tokai & Sannohara & 2 & 2 & Preboreal \\
\hline Tokai & Uegahira & 4 & 2 & Preboreal \\
\hline W Honshu & Awazu Kotei & 5 & 1 & Preboreal \\
\hline W Honshu & Besyotsujido & 1 & 1 & Preboreal \\
\hline W Honshu & Irienaiko & 17 & 5 & < 8500 B.P. \\
\hline W Honshu & Kuroshima shell mound & 4 & 3 & Preboreal \\
\hline
\end{tabular}




\begin{tabular}{|c|c|c|c|}
\hline & \multicolumn{3}{|c|}{ NISP of Pottery } \\
\hline Chronozones & Number of pottery assemblages & Median & Maximum \\
\hline Bølling/Aller $\varnothing \mathrm{d}$ & 10 & 341 & 3000 \\
Younger Dryas & 2 & 270 & 498 \\
Preboreal & 12 & 1134 & 33000 \\
\hline
\end{tabular}

Table 3 